\title{
Electrospun Composite Nanofibers Based on Poly ( $\varepsilon$-caprolactone) and Styrax Liquidus (Liquidambar Orientalis Miller) as a Wound Dressing: Preparation, Characterization, Biological and Cytocompatibility Results
}

\section{Didem Demir}

Mersin University: Mersin Universitesi

\section{Sadin Özdemir}

Mersin University: Mersin Universitesi

\section{Seda Ceylan}

Adana Alparslan Turkes Science and Technology University: Adana Alparslan Turkes Bilim ve Teknoloji Universitesi

\section{Serkan Yalcin}

Mersin University: Mersin Universitesi

\section{Burcu Sakım}

Mersin University: Mersin Universitesi

Nimet Bölgen ( $\square$ nimetbolgen@yahoo.com )

Mersin University: Mersin Universitesi https://orcid.org/0000-0003-3162-0803

\section{Research Article}

Keywords: poly ( $\varepsilon$-caprolactone), styrax, Liquidambar orientalis Miller, nanofiber, wound dressing, tissue engineering

Posted Date: September 30th, 2021

DOI: https://doi.org/10.21203/rs.3.rs-898724/v1

License: (c) (1) This work is licensed under a Creative Commons Attribution 4.0 International License. Read Full License

Version of Record: A version of this preprint was published at Journal of Polymers and the Environment on January 13th, 2022. See the published version at https://doi.org/10.1007/s10924-022-02376-7. 


\section{Abstract}

In this study, styrax liquidus (sweet gum balsam) extracted from Liquidambar orientalis Mil. incorporated PCL fibrous scaffolds were prepared using the electrospinning method. The effects of the styrax liquidus content on the prepared scaffolds were investigated using different physico-chemical and morphological analyses. Then, the styrax-loaded nanofibers were examined for their antioxidant activity, anti-biofilm, metal chelating, antimicrobial and DNA cleavage properties. The results obtained from these studies showed that the nanofibers exhibited effective biological activity depending on the weight ratio of the styrax liquidus. In light of the data obtained from the characterization and biological studies, a sample with high ratio of balsam was built for determining the cytocompatibility analysis in vitro. The cytotoxicity studies of the selected membrane were conducted using mouse embryonic fibroblast cells. The fibrous scaffolds lead to increase the cell number as a result of high viability. According to the results, we propose a novel biocompatible electrospun hybrid scaffold with antioxidant and antimicrobial properties that can be used as wound healing material for potential tissue engineering applications.

\section{Introduction}

Donor waiting list have more than 100,000 patients at any given time and an average of 22 people die each day while waiting for organ or tissue transportation [1]. One of the aims of tissue engineering is to produce organs or tissues in laboratory conditions to solve this problem with the combinations of biomaterials, cells, and/or bioactive molecules [2, 3]. Materials prepared with the approach of tissue engineering called scaffolds can be used for tissue regeneration, wound healing and drug delivery applications and these biomaterials can be produced by using biodegradable and biocompatible polymers. Chitosan, collagen, starch, hyaluronic acid, laminin, etc. are the natural and biodegradable polymers commonly used in the regeneration of tissues [4,5]. Synthetic polymers [poly ( $\varepsilon$-caprolactone), poly (L-lactic acid), polyurethane, polytetrafluoroethylene or teflon, etc.] are commonly produced from non-renewable resources by using chemical process such as petroleum. Synthetic or natural polymers have been used in different combinations with ceramics or essential oils of medical plants to mimic the targeted tissue in various studies [6-9]. By incorporation of these materials into the polymeric scaffolds, an ideal biomaterial can be obtained via mimicking the both physical and chemical properties of the natural extracellular matrix which is the important step of the production process [10,11]. In a study, natural biosilica was isolated and incorporated with Poly (DL-lactide -co - glycolide) (PDLGA) polymer to compare the degradation profile of pure biosilica and biosilica with PDLGA [12]. Tanaka et al. produced chitosan loaded with dibasic calcium phosphate anhydrous for dental applications [13].

Poly ( $\varepsilon$-caprolactone) (PCL) based biomaterials are commonly used as scaffold in various tissue engineering applications such as nerve tissue engineering, skin tissue engineering and bone regeneration. However, biologically biodegradable PCL scaffold requires improving the various limited characteristic properties such as hydrophobic nature, low stiffness and cell affinity to obtain optimum scaffold [14]. These drawbacks are accomplished in different studies by incorporating silicon dioxide $\left(\mathrm{SiO}_{2}\right)$ and hydroxyapatite (HAp) [11], chondroitin sulphate and gelatin [14], aleo-vera and collagen [15] into the PCL 
matrix. Recently, incorporation of medicinal plants into bioactive scaffolds and their controlled release in the damaged tissue is a novel approach to prevent infections, control the inflammation, as well as accelerate the skin tissue regeneration such as ulcers and burns healing [9]. In addition to acceleration wound healing, an ideal skin tissue engineering scaffold enables to protect wound from infection, fluid loss and provide a stable template for the synthesis of neo- dermal tissue [16].

Liquidambar orientalis Miller, also called as Anatolian sweet gum, a medical plant is an endemic tree species in the Mediterranean region $[17,18]$. Liquidambar orientalis Mill. is known to have cosmetic and medicinal properties and used for the treatment of some skin diseases in Turkish folk medicine [19]. The styrax liquidus is a plant secondary metabolite that possess several biological effects including antibacterial, antifungal, antioxidant, nematocidal activities as well as inhibitory effect on the central nervous system [19-24]. These properties of the styrax liquidus can be illustrated from main components of $L$. orientalis such as styrene, terpinen-4-ol, a-terpineol , a-pinene and veridiflorol [25, 26]. Different scientific studies of research areas have shown the L. orientalis effects on disabilities. For example, Sağdıç et al., investigated the antimicrobial properties of styrax against 20 different strains of bacteria using an agar diffusion method [27]. In addition to this, Gürbüz et al., presented the anti-ulcerogenic activity of styrax [20]. Phenolic compounds and antioxidant, mutagenic and antimutagenic activities were also studied by Saraç et al. [18].

To our knowledge, there is no scientific study about of the characteristic properties, biological and cytotoxicity activities of the styrax or styrax combined with polymeric scaffolds. Herein, we report for the first time a simple method for processing traditional electrospun PCL nanofiber membranes incorporating styrax liquidus for skin tissue engineering applications. Characterization properties, detailed biological evaluation (DPPH radical scavenging assay, ferrous ion chelating activity, biofilm inhibition activity, DNA cleavage and antimicrobial activity) and cytotoxicity investigations were reported. Based on our results, the styrax liquidus incorporated electrospun hybrid membrane with tailorable characteristics might be used as an alternative candidate for skin tissue engineering applications as a wound healing material.

\section{Materials And Methods}

\subsection{Materials}

PCL with an average molecular weight of $80 \mathrm{kDa}$ was supplied from Sigma-Aldrich, United Kingdom. The solvents, chloroform and dimethylformamide, were obtained from Tekkim (Turkey) and Carlo Erba Reagents (France), respectively. The styrax liquidus was purchased from a local herbalist in Muğla Province, Turkey. 2,2-diphenyl-1-picrylhydrazyl (DPPH), ascorbic acid, trolox and pBR322 plasmid DNA were purchased from Sigma Aldrich, USA to be used in antimicrobial studies.

\subsection{Electrospinning process for preparation of neat and styrax liquidus loaded PCL nanofibers}

Nanofibrous scaffolds were manufactured via electrospinning method by using a high voltage power supply (Gamma, ES40P, USA) as previously described in our studies $[28,29]$. Briefly, a PCL solution with a 
concentration of $13 \%(\mathrm{w} / \mathrm{v})$ was prepared by dissolving the calculated amount of polymer in a solvent mixture containing 30:70 volumetric ratio of $\mathrm{CH}$ and DMF, respectively. $2 \mathrm{~mL}$ of the prepared solution was placed into a plastic syringe and the syringe was placed horizontally on a syringe pump (New Era, NR300 , USA) The $1 \mathrm{~mL} / \mathrm{h}$ feed rate and $13 \mathrm{kV}$ voltage were applied for $30 \mathrm{~min}$ to produce the nanofibers. Distance from tip to the collector was set to $10 \mathrm{~cm}$.

The hybrid nanofibers were prepared with different weight ratios of styrax liquidus based on the polymer weight $(25,50$ and $100 \%$, wt). The abbreviated names of the blank PCL and the samples produced based on the amount of or styrax liquidus added are PCL, PCL25\%, PCL50\% and PCL $100 \%$, respectively. The determined weight of balsam added PCL solutions were stirred at $750 \mathrm{rpm}$ at room temperature until a homogeneous polymer-styrax mixture was obtained. Then, the blend solution was used for the preparation of composite nanofibers according the electrospinning process conditions described below for preparation of neat PCL fibers. The basic experimental set-up for the electrospinning of neat PCL and or styrax liquidus loaded PCL composite nanofibers was illustrated in Figure 1.

\subsection{Characterization Studies}

The chemical characterization of the samples was conducted by FTIR (PerkinElmer 400 FT-IR/FT-FIR). The spectra were obtained over the range $400-4000 \mathrm{~cm}^{-1}$ at a resolution of $4 \mathrm{~cm}^{-1}$. The morphological appearance of the nanofibers was evaluated by SEM (SUPRA 55, Carl Zeiss, Germany). Prior to SEM imaging, the samples were coated with a thin layer of platinum using a sputter coater. Samples were then analyzed using a voltage of $5 \mathrm{kV}$ at different magnifications. The fiber diameter histograms were created using the measurement data obtained by Image-J Software by measuring 100 fiber diameters for each sample. To evaluate the effect of different amounts of styrax liquidus on the hydrophilicity of PCL nanofibers, water contact angles were measured using a contact angle analyser by the sessile drop method (Attension, Biolin Scientific, Sweden). Measurements were obtained at five in- dependent points and presented as mean standard deviation. The photographs were taken at the end of the 5 seconds after contact of the water droplet with the nanofibrous membrane by a camera levelled with the surface. To reveal the wettability properties of the produced nanofibrous scaffolds, the gravimetric measurements of water uptake capacity analysis were done after immersion of samples in distilled water at pre-determined time intervals $(1,5,15$ and $30 \mathrm{~min})$. Before the analysis, dry weights of the samples were recorded $\left(M_{0}\right)$.

Then, samples were immersed into distilled water. At certain times, the membranes were taken out and excess water from the surface of the membranes was removed with filter paper and samples were weighed $\left(M_{t}\right)$. The capacity of water uptake $(w / w, \%)$ was calculated for each sample using the following equation:

Water uptake capacity, \%= $\left[\left(\mathrm{M}_{\mathrm{t}}-\mathrm{M}_{0}\right) / \mathrm{M}_{0}\right] * 100$

\subsection{Biological Evaluation}

\subsubsection{DPPH radical scavenging assay}


Antioxidant activities of plain PCL and different weight ratios of styrax loaded PCL nanofibers were determined through the removal of the free DPPH (2,2-diphenyl-1-picrylhydrazyl) radical according to the Blois method [30]. $0.1 \mathrm{~g}$ of sample from each fibrous scaffold was suspended in $50 \mathrm{~mL}$ of dimethylformamide solution and then sonicated for $60 \mathrm{~min}$ and stored at room temperature for overnight. Different concentrations of the supernatant were prepared. Then, $0.5 \mathrm{ml}$ of these and $2 \mathrm{~mL}$ of DPPH radical solution were mixed. After 30 min of incubation in a dark place, the measurement was accomplished in a spectrophotometer (Shimadzu UV-1800, Japan) using $517 \mathrm{~nm}$ as wavelength. The results were recorded as a percentage of inhibition of DPPH free radical as described below.

DPPH free radical activity, $\left.\%=\left[\left(\mathrm{Abs}_{\text {control }}-\mathrm{Abs}_{\text {sample }}\right) / A b \mathrm{~s}_{\text {control }}\right)\right] \times 100$

\subsubsection{Ferrous ion chelating activity}

The metal chelating potency of plain PCL and different weight ratios of styrax loaded PCL nanofibers were studied according to the method [31]. The $\mathrm{Fe}^{2+}$ chelating ability of nanofibers was monitored by measuring the absorbance of the magenta color of ferrous-ferrozine complex. The reaction mixture, containing $1 \mathrm{~mL}$ nanofibers of different concentration, $0.1 \mathrm{~mL} \mathrm{FeCl} 2 \cdot \mathrm{H}_{2} \mathrm{O}(2 \mathrm{mM}), 0.2 \mathrm{~mL}$ ferrozine-1,2,4-triazine ( $5 \mathrm{mM}$ ), was completed to a total volume of $5.0 \mathrm{~mL}$ with the solvent used. This solution was mixed and kept for 10 minutes at room temperature. The same protocol was applied to EDTA as a positive control. The activities were recorded spectrophotometrically at $562 \mathrm{~nm}$. The ability of ferrous ion chelating was calculated using the following formula:

Ferrous ion chelating effect, $\%=\left[\left(\mathrm{Abs}_{\text {control }}-\mathrm{Abs}_{\text {sample }}\right) / \mathrm{Abs}_{\text {control }}\right] \times 100$

\subsubsection{Biofilm inhibition activity}

S. aureus (ATCC 6538) and P. aeruginosa (ATCC 9027) were used for the biofilm inhibition. The test compounds were added to the wells $(250 \mathrm{mg} / \mathrm{mL}$ and $500 \mathrm{mg} / \mathrm{mL})$ and then microorganisms were incubated in the oven at $37^{\circ} \mathrm{C}$ for 48 hours. After the incubation time, the medium was removed from the plates and the wells were washed 2 times with distilled water. The plates were left to dry at $80^{\circ} \mathrm{C}$ for half an hour and then crystal violet was added to each well and held for 60 minutes. After 60 minutes, the crystal violet was removed from the wells and each well was rinsed 2 times with distilled water. Then, alcohol was added to each well and the measurement was taken on a spectrophotometer at $595 \mathrm{~nm}$. The wells with no compound were used as a control. Biofilm inhibition was calculated according to the formula below.

Biofilm inhibition $=\left[\left(\right.\right.$ Abs $_{\text {control }}-$ Abs $\left._{\text {sample }}\right) /$ Abs $\left._{\text {control }}\right] \times 100$

\subsubsection{DNA cleavage activity}

The DNA cleavage activity of nanofibers was monitored by agarose gel electrophoresis on pBR 322 plasmid DNA. pBR 322 DNA $(0.1 \mu \mathrm{g} / \mu \mathrm{L})$ in Tris- $\mathrm{HCl} 50 \mathrm{mM}$ and $\mathrm{NaCl}$ buffer $(18 \mathrm{mM}$; pH:7.2) was reacted 
with test samples. All sample mixtures were incubated at $37^{\circ} \mathrm{C}$ for 90 min and then loaded with loading dye on a \%1 agarose gel containing ethidium bromide. The gel electrophoresed for $120 \mathrm{~min}$ at $80 \mathrm{~V}$ in Tris/Borate/EDTA buffer. The bands formed were monitored by UV-A light and photographed.

\subsubsection{Antimicrobial activity}

Antimicrobial activity of nanofibrous scaffolds was tested against one yeast (Candida albicans), and six bacterial strain (Enterococcus hirae (ATCC 10541), Bacillus cereus, Staphylococcus aureus (ATCC 6538), Pseudomonas aeruginosa (ATCC 9027), Legionella pneumophila subsp. Pneumophila (ATCC 33152) and Escherichia coli (ATCC 10536)). These microorganisms (about $10^{8}-10^{9}$ colony forming units $(\mathrm{CFU} / \mathrm{mL})$ ) were inoculated in Nutrient broth medium containing different concentrations of nanofibers. Culture media were then incubated at $120 \mathrm{rpm}$ for a day in a shaker at $37^{\circ} \mathrm{C}$ [32]. Antibacterial activities were evaluated by determined the minimum inhibition concentrations (MICs) of the samples.

\subsection{Cytocompatibilty Studies}

\subsubsection{Cell culture conditions}

The cytotoxicity studies of the styrax loaded PCL fibrous scaffold were performed with MEF (CF-1) (ATCC1SCRC- $1040^{\mathrm{TM}}$ ) cell line. The cells were incubated at $37^{\circ} \mathrm{C}$ in a humidified atmosphere of $95 \%$ air and $5 \% \mathrm{CO}_{2}$ in a humidified incubator (NUAIRE, NU-5800, USA) with high-glucose Dulbecco's-modified Eagle's medium (DMEM, Lonza, Belgium) supplemented with 10\% fetal bovine serum (FBS, Lonza, Belgium) and $55 \mu \mathrm{M} \beta$-mercaptoethanol (Merck, Germany).

\subsubsection{Direct and indirect test}

To determine the cytocompatibility of the fibrous scaffold with MEF cells, PCL100\% nanofiber scaffolds was chosen, because of its good physical properties in terms of hydrophilicity. In vitro cytotoxicity study of the scaffolds was carried out by two assays, direct and indirect assay, respectively. For the direct assay, scaffolds were cut into $1 \times 1 \mathrm{~cm}^{2}$ square pieces, sterilized in $70 \%$ ethanol for $2 \mathrm{~h}$ and then washed with phosphate buffer saline (PBS). After that process, the cultured MEF cells were seeded on the membranes ( $3 \times 10^{4}$ cells/membrane) in 24-well plates. In case of direct contact assay, the scaffold samples with cells left in the incubator for 1, 3 and 5 days. Viability of cells on scaffolds was determined using the 3-(4,5-Dimethylthiazol-2-yl)-2,5-diphenyltetrazolium bromide (MTT) assay after the incubation times.

In-direct assay of the scaffolds was carried out by two groups. For the control group, standard medium (DMEM - 10\% FBS and $55 \mu \mathrm{M} \beta$-mercaptoethanol) medium were given to the cells. For the test groups, the fibrous scaffolds incubated (DMEM - 10\% FBS and $55 \mu \mathrm{M} \beta$-mercaptoethanol with degradation products of membranes) medium were given to test groups. The membranes prepared in $1 \times 1 \mathrm{~cm}^{2}$ square pieces were sterilized in $70 \%$ ethanol for $2 \mathrm{~h}$, washed with PBS and transferred to the medium. For the indirect assay, $15000 \mathrm{MEF}$ cells were seeded into the 6-well plates and incubated at $37^{\circ} \mathrm{C}$ in a humidified 
$5 \% \mathrm{CO}_{2}$. The cell viability of control and test groups was compared at end of the 1,3 and 5 days by performing MTT assay. The assays were performed in triplicate [33].

\section{Results And Discussion}

\subsection{Characterization of plain PCL and styrax loaded PCL nanofibers}

The FTIR spectroscopy presented in Figure 2A was employed to reveal the presence of styrax in the structure of PCL nanofibers and the effect of different amounts of styrax on the chemical characteristics of nanofibers. When the spectra of electrospun membranes prepared at different proportions of content are examined, it was seen that there was no significant change in the basic functional groups of PCL after being loaded with styrax. The nanofibrous membranes exhibited characteristic peaks of PCL located at 2940, 2865 and $1722 \mathrm{~cm}^{-1}$ attributed to the stretchings of $-\mathrm{CH}_{3},-\mathrm{CH}_{2}$ and $\mathrm{C}=0$, respectively [34, 35]. In addition, the spectra showed the other absorption bands of PCL located at 1296 (C-0 stretching), 1245 (asymmetric C-O-C strecthing) and $1190 \mathrm{~cm}^{-1}$ (asymmetric O-C-O strecthing) [36, 37]. Although these signals were displayed by all samples and no changes in the positions of these peaks were noted (including the spectrum of PCL-styrax composites), a significant increase in the intensity of the peaks was observed with the increasing amount of styrax. Nevertheless, a new peak around $1640 \mathrm{~cm}^{-1}$ corresponding to the double bond stretching vibration of $\mathrm{C}=\mathrm{C}$ group of styrene, the main component of styrax shown in Figure2B, was observed in composites with high rates of styrax (PCL50\% and PCL100\%) $[20,38]$. These changes show that styrax is successfully dispersed in nanofiber composites.

SEM was performed for accounting any difference in morphology of the PCL nanofiber blends with different amounts of styrax liquidus as compared to neat PCL fibers. With this approach, the morphological changes and size distribution histograms of the samples are presented in Figure 3 and Figure 4, respectively. All nanofibrous scaffolds had uniform and bead-free network structure with good continuity and smoothness. The morphological evaluation indicated that the structure of the electrospun nanofibers depended on the balsam concentration. As the weight ratio of balsam based on the polymer weight increased to 25,50 and $100 \%$, nanofibers started to be heterogeneous in structure. On the other hand, the mean fiber diameter obviously increased with the addition of styrax in the recipe. The average diameter for neat PCL fibers was calculated to be $\sim 188.75 \pm 44.54 \mathrm{~nm}$. The styrax loaded hybrid fibers showed the diameters of around $192.70 \pm 58.33,316.11 \pm 102.29$, and $371.27 \pm 108.61 \mathrm{~nm}$ for PCL25\%, PCL50\%, and PCL100\%, respectively. These differences in mean fiber diameter may be attributed to the encapsulation of styrax in PCL fibers. According to this change, when the high-magnification SEM images of high balsam content nanofibers examined, the styrax loaded capsules indicated by yellow arrows can clearly be seen in Figures $3 \mathrm{G}$ and $3 \mathrm{H}$. This similar structural change occurring in fiber morphology were also observed in the Hypericum perforatum oil-loaded fibrous membranes developed by Eğri and Erdemir [39].

Hydrophilicity and wettability of the membranes which are the important features for wound dressings were evaluated by determining the contact angle and water uptake capacity, respectively. From Figure 5A, 
the contact angle of all samples is found to be $90^{\circ}$, showing the hydrophobic nature of the nanofibrous scaffolds. The pristine PCL mat is more hydrophobic $\left(127.07 \pm 1.03^{\circ}\right)$ than the PCL25\%, PCL50\% and PCL100\% samples and their contact angle are $124.02 \pm 0.69,118.01 \pm 0.73$ and $113.66 \pm 2.38$, respectively. In different research articles, similar to hydrophobic nature of PCL, polyurethane-turmeric oil [40], and polyurethane-grape seed oil/honey/propolis incorporations resulted contact angle decrease compared with pure polyurethane scaffold [41]. The change in hydrophilicity as a result of adding a plant-based oil to the PCL synthetic polymer was evaluated in the study conducted by Ünalan et al. and they showed that loading of increasing amounts of peppermint essential oil on electrospun PCL fiber mats decreased the contact angle of the plain PCL fibrous mat [42].

On the other hand, to determine the water uptake ability of the scaffolds, gravimetric measurements were performed after immersion of samples in distilled water until the equilibrium water uptake capacity is reached. According to the results shown in Figure 5B, the water uptake capacity of high amounts of styrax liquidus incorporated nanofibers (PCL50\% and PCL100\%) was significantly different than the neat PCL fibrous sample. This result is dependent on the hydrophilic/hydrophobic nature of the materials as well as on the morphological properties of the nanofibers [43]. As we mentioned above, the surface of membranes have acquired a little hydrophilic property with the addition of styrax liquidus and consequently, their water uptake capacity may have increased. Additionally, the increase in pore size (Figure 3) with the addition of styrax may have also affected the swelling capacity because the high porosity can be defined as the presence of more free space available for water uptake [44].

\subsection{DPPH Radical Scavenging Activity}

It is generally known that the wound healing properties of plant derivatives are significantly associated with their antioxidant activities. Therefore, the antioxidant activity determined by measuring the DPPH radical scavenging activity of PCL and styrax loaded PCL (PCL25\%, PCL50\% and PCL100\%) nanofibers was evaluated and the results were represented in Figure 6A. It was shown that plain PCL and different amounts of styrax loaded PCL nanofibers exhibited well antioxidant activity in comparison with the positive controls trolox and ascorbic acid. When the concentration of nanofibers was increased from 25 $\mathrm{mg} / \mathrm{L}$ to $500 \mathrm{mg} / \mathrm{L}$, the DPPH radical scavenging activities were increased from $26.4 \%$ to $71.4 \%$, from $33.6 \%$ to $78.5 \%$, from $54.4 \%$ to $82.7 \%$, and from $63.5 \%$ to $86.7 \%$, respectively. PCL $100 \%$ sample was found to has a more effective DPPH radical scavenging ability at all concentrations. According to the results, radical scavenging potencies were concentration-dependent. It was observed that the antioxidant effect increased as the proportion of the styrax in PCL nanofibrous samples increased. The results are compatible with the literature [45]. Furthermore, this study results indicated that the styrax-PCL hybrid nanofibrous membrane could be used as a potential antioxidant biomaterial for future wound healing applications.

\subsection{Metal chelating activity}

Ferrous ion chelating activities of plain PCL, and PCL\%25, PCL\%50, and PCL $\% 100$ samples were studied by the ferrozine test. In the presence of chelating agents, the formation of ferrous-ferrozine complex is 
inhibited so that the magenta color of the complex is bleach. The results of the test prove that all samples exhibited chelating activities as seen in Figure 6B, chelating activities also were concentrationdependent. The ferrous ion chelating activities at $100 \mathrm{mg} / \mathrm{L}$ were $50.7 \%, 55.2 \%, 59.0 \%$, and $63.0 \%$, for PCL, PCL25\%, PCL50\%, and PCL100\%, respectively. According to method applied tested nanofibers also exhibited chelating ability in the order of PCL100\% (71.7\%) > PCL50\% (66.6\%) > PCL25\% (63.7\%) > PCL $(57.9 \%)$ at concentration of $200 \mathrm{mg} / \mathrm{L}$. Metal ion chelating capacity is important since it reduces the concentration of the transition metal that catalyzes lipid peroxidation [46]. The metal chelating capacity of the styrax in PCL nanofiber is not good as the standard EDTA, but the decrease in concentrationdependent color formation in the presence of nanofibrous membranes indicates that it can be used as a metal chelator.

\subsection{Biofilm inhibition activity}

Biofilm formation as a result of bacterial infections is one of the most important and undesirable parameters that delay wound healing [47]. Biofilm-forming cells exhibit greater resistance to antibiotics, biocides, and extreme conditions than planktonic cells. In addition, biofilm cells are more difficult to remove or inactivate $[48,49]$. In this method, the effect of PCL, PCL25\%, PCL50\% and PCL $100 \%$ at 250 $\mathrm{mg} / \mathrm{L}$ and $500 \mathrm{mg} / \mathrm{L}$ concentrations against the $P$. aeruginosa and $S$. aureus biofilm formed on polystyrene microplates was estimated by measuring the population of viable cells. P. aeruginosa and $S$. aureus are bacteria colonizing around the chronic wounds [47]. As shown in Figure 6C, when the concentration of PCL\%0, PCL\%25, PCL\%50, and PCL\%100 was increased from $250 \mathrm{mg} / \mathrm{L}$ to $500 \mathrm{mg} / \mathrm{L}$, the biofilm inhibition activities against $P$. aeruginosa were increased from $59.4 \%$ to $68.3 \%$, from $76.5 \%$ to $78.9 \%$, from $83.0 \%$ to $85.0 \%$, and from $86.5 \%$ to $90.6 \%$, respectively. Similar results were obtained against the $S$. aureus and PCL $100 \%$ showed the highest activity $(93.3 \%)$ at $500 \mathrm{mg} / \mathrm{L}$ concentration. Obtained results prove that styrax in PCL nanofibers have the potential to be applied as an antibacterial and antibiofilm agent to combat $P$. aeruginosa and $S$. aureus which are the most commonly encountered bacterial species in infected chronic wounds.

\subsection{DNA cleavage activity}

To determine the functionality of neat PCL and different amounts of styrax incorporated PCL nanofibers as DNA cleavage agents, the materials were investigated using supercoiled pBR322 plasmid DNA. The efficiency of the samples was tested by agarose gel electrophoresis. The results of the study are depicted in Figure 6D. At $250 \mu \mathrm{g} / \mathrm{mL}$ concentration, neat PCL did not exhibit cleavage activity (lane 2). Whereas, PCL25\%, PCL50\%, and PCL100\% demonstrated single-strand cleaved DNA activities in lane 3, lane 4, and

lane 5, respectively. At $500 \mu \mathrm{g} / \mathrm{mL}$ concentration, PCL25\%, PCL50\%, and PCL100\% successfully cleaved DNA and double-strand DNA occured in lane 7, lane 8, and lane 9, respectively. Generally, the results suggest that Liquidambar orientalis Miller in PCL nanofibers have the potential as functional materials for medicine industries after further studies.

\subsection{Antimicrobial activities}


In vitro antimicrobial potentials of PCL, PCL25\%, PCL50\% and PCL $100 \%$ were scrutinized in terms of minimum inhibition concentration (MIC) value against Gram-positive, Gram-negative bacteria and a fungal strain. MIC values obtained from the study are presented in Table 1. As can be seen, PCL and PCL25\% were exhibited weak antimicrobial activity against all tested microorganism. Whereas PCL50\% and PCL $100 \%$ were shown well antimicrobial activity ranging from 16 to $64 \mu \mathrm{g} / \mathrm{mL}$ against tested Gramnegative bacteria E. coli, L. pneumophila, and $P$. aeruginosa. In addition to this, they were exhibited moderate antimicrobial activity ranging from 16 to $128 \mu \mathrm{g} / \mathrm{mL}$ against tested Gram-positive bacteria $B$. cereus, S. aureus, E. hirae, and fungus $C$. albicans. The neat PCL nanofibers did not display significant antibacterial activity. Similarly, a novel active film made of PCL containing sage extract was developed by Salevic et al. and they reported that plain PCL has no antibacterial effect [50]. In our study, styrax in PCL nanofiber samples (PCL 50\% and PCL 100\%) showed good antimicrobial activity. These results are in agreement with the other studies $[19,21]$. The mechanism of biocidal action of plant-derived compounds is based on the degradation of the cell wall, damage to cytoplasmic membrane and membrane proteins, leakage of content out of the cell, and coagulation of the cytoplasm [50,51]. The different antimicrobial activity of our samples against microorganisms can be attributed to the differences in the cell wall structure of Gram-positive and Gram-negative bacteria. According to our results, styrax loaded PCL nanofibrous membranes can be used as antimicrobial materials.

Table 1. The minimum inhibition concentration of tested microorganisms

\begin{tabular}{|lllll|}
\hline \multirow{5}{*}{ Bacteria } & PCL & PCL25\% & PCL50\% & PCL100\% \\
\cline { 2 - 5 } E. coli & 128 & 64 & 32 & 16 \\
\hline B. cereus & 256 & 256 & 128 & 128 \\
\hline Legionella & 128 & 64 & 32 & 16 \\
\hline S. aureus & 128 & 64 & 32 & 16 \\
\hline P. aeruginosa & 256 & 128 & 64 & 32 \\
\hline E. hirae & 256 & 128 & 64 & 64 \\
\hline C. albicans & 512 & 256 & 128 & 64 \\
\hline
\end{tabular}

${ }^{*} \mathrm{mg} / \mathrm{L}$

\subsection{Cell Viability}

In vitro cellular response to PCL100\% nanofibers is presented in Figure 7. Direct test shows that PCL100\% nanofiber scaffolds showed better cell viability compared to the control group. As it can be seen, there is significant difference between the cell viability of control group and PCL $100 \%$ nanofiber samples at different days (Figure 7A). The PCL100\% nanofiber showed cell proliferation rate 65.76 
$\pm 0.62 \%, 299.25 \pm 2.2 \%$, and $497.48 \pm 0.37 \%$, at 1,3 and 5 day, respectively. The PCL $100 \%$ nanofiber showed better cell proliferation rates than the control group. It was reported that the membrane with styrax enhanced adhesion and proliferation of MEF cells. The addition of styrax increased the hydrophilic nature of the pristine PCL membrane which might have favoured the enhanced MEF cell viability. In addition to this, styrax includes also active compounds such as; terpinen-4-ol, a-terpineol, sabinene, apinene, veridiflorol and p-cymene which are known to promote cell proliferation and have an antimicrobial activity on bacteria and fungi $[20,52]$. However, the indirect cell proliferation rates for control group (standard medium) were higher compared to the PCL100\% nanofiber (medium with PCL100\% nanofiber degradation products) (Figure 7B). Such a behaviour has been reported before and needs further investigations. This might be due to the long term incubation of PCL100\% nanofiber in medium (7 day) as described in different study [53]. Various investigations presents that PCL scaffold incubated one or three day in medium and results show that cell viability value was lower than the control group with this medium $[54,55]$.

\section{Conclusions}

Electrospun neat PCL and novel hybrid PCL fibers prepared with different amounts of styrax liquidus were developed and characterized. The obtained membranes possessed a homogeneous morphology with smooth and uniform nanofibers. FTIR analysis confirmed the presence of styrax in PCL nanofibers. In addition, electrospray encapsulated styrax droplets were imaged on the fibers presented in SEM images. Neat PCL membranes, which are in hydrophobic nature, have gained a slightly hydrophilic feature with the additive of styrax. Furthermore, the biological evaluation of electrospun fiber mats was evaluated in detail using DPPH radical scavenging, metal chelating, biofilm inhibition and DNA cleavage activities, and antimicrobial studies against gram-positive, gram-negative bacteria and a fungal strain. Our results showed that the styrax loaded fibrous membranes could be used as potential antioxidant and antimicrobial biomaterial that do not allow biofilm formation for accelerate wound healing applications. For biocompatibility evaluation, the selected membrane with high ratio of styrax content was studied with MEF cells. The cell viability results indicated that the addition of styrax and degradation products of the membrane did not induce cytotoxicity, although it enhanced the cell adhesion and proliferation. Overall, our results indicate that the styrax loaded hybrid nanofibrous mats have potential to be used as a new antibiotic-free bacterial infection treatment for wound healing applications.

\section{Declarations}

Funding: Not applicable

Conflicts of interest: The authors confirm that no conflict of interest occurred in this study.

Availability of data and material: This article has no additional data.

Code availability: Not applicable

Page $11 / 22$ 
Authors' contributions: Authors' contributions: All authors contributed to the study conception and design. Nanofibrous materials preparation, data collection and characterization analysis of samples were performed by D. Demir, B. Sakım and N. Bölgen. Biological activity analysis and data collection were performed by M. S. Yalçın and S. Özdemir. S. Ceylan performed the cytotoxicity studies and data collection. The first draft of the manuscript was written by D. Demir, S. Ceylan, M. S. Yalçın, S. Özdemir and N. Bölgen. All authors commented on previous versions of the manuscript. All authors read and approved the final manuscript.

\section{References}

1. Gershlak JR, Hernandez S, Fontana G, et al (2017) Crossing kingdoms: Using decellularized plants as perfusable tissue engineering scaffolds. Biomaterials 125:13-22. https://doi.org/10.1016/j.biomaterials.2017.02.011

2. Qu M, Jiang X, Zhou X, et al (2020) Stimuli-Responsive Delivery of Growth Factors for Tissue Engineering. Adv Healthc Mater 1901714:1-19. https://doi.org/10.1002/adhm.201901714

3. Liu S, Zheng Y, Wu Z, et al (2020) Preparation and characterization of aspirin-loaded polylactic acid/graphene oxide biomimetic nanofibrous scaffolds. Polymer (Guildf) 211:123093. https://doi.org/10.1016/j.polymer.2020.123093

4. Sundar G, Joseph J, Prabhakumari C, et al (2020) Natural collagen bioscaffolds for skin tissue engineering strategies in burns: a critical review. Int J Polym Mater Polym Biomater 0:1-12. https://doi.org/10.1080/00914037.2020.1740991

5. Yang X, Wang B, Sha D, et al (2020) Injectable and antibacterial $\varepsilon$-poly(L-lysine)-modified poly(vinyl alcohol)/chitosan/AgNPs hydrogels as wound healing dressings. Polymer (Guildf) 123155. https://doi.org/10.1016/j.polymer.2020.123155

6. Pandele AM, Ionita M, Crica L, et al (2017) Novel Chitosan-poly(vinyl alcohol)/graphene oxide biocomposites 3D porous scaffolds. Compos Part B Eng 126:81-87. https://doi.org/10.1016/j.compositesb.2017.06.010

7. Yar M, Gigliobianco G, Shahzadi L, et al (2016) Production of chitosan PVA PCL hydrogels to bind heparin and induce angiogenesis. Int J Polym Mater Polym Biomater 65:466-476. https://doi.org/10.1080/00914037.2015.1129959

8. Baghaie S, Khorasani MT, Zarrabi A, Moshtaghian J (2017) Wound healing properties of PVA/starch/chitosan hydrogel membranes with nano Zinc oxide as antibacterial wound dressing material. J Biomater Sci Polym Ed 28:2220-2241. https://doi.org/10.1080/09205063.2017.1390383

9. Güneş S, Tıhmınlıoğlu F (2017) Hypericum perforatum incorporated chitosan films as potential bioactive wound dressing material. Int J Biol Macromol 102:933-943. https://doi.org/10.1016/j.ijbiomac.2017.04.080

10. Yao Q, Liu Y, Pan Y, et al (2020) One-pot porogen free method fabricated porous microsphereaggregated 3D PCL scaffolds for bone tissue engineering. J Biomed Mater Res - Part B Appl Biomater 1-12. https://doi.org/10.1002/jbm.b.34601 
11. Pattanashetti NA, Viana T, Alves N, et al (2020) Development of novel 3D scaffolds using BioExtruder by varying the content of hydroxyapatite and silica in PCL matrix for bone tissue engineering. $J$ Polym Res 27:. https://doi.org/10.1007/s10965-020-02053-0

12. Han R, Buchanan F, Ford L, et al (2021) A comparison of the degradation behaviour of 3D printed PDLGA scaffolds incorporating bioglass or biosilica. Mater Sci Eng C 120:111755. https://doi.org/10.1016/j.msec.2020.111755

13. Tanaka CB, Lopes DP, Kikuchi LNT, et al (2020) Development of novel dental restorative composites with dibasic calcium phosphate loaded chitosan fillers. Dent Mater 36:551-559. https://doi.org/10.1016/j.dental.2020.02.004

14. Sharifi F, Irani S, Azadegan G, et al (2020) Co-electrospun gelatin-chondroitin sulfate/polycaprolactone nanofibrous scaffolds for cartilage tissue engineering. Bioact Carbohydrates Diet Fibre 22:100215. https://doi.org/10.1016/j.bcdf.2020.100215

15. Ghorbani M, Nezhad-Mokhtari P, Ramazani S (2020) Aloe vera-loaded nanofibrous scaffold based on Zein/Polycaprolactone/Collagen for wound healing. Int J Biol Macromol 153:921-930. https://doi.org/10.1016/j.jjbiomac.2020.03.036

16. Garric X, Guillaume O, Dabboue H, et al (2012) Potential of a PLA-PEO-PLA-based scaffold for skin tissue engineering: In vitro evaluation. J Biomater Sci Polym Ed 23:1687-1700. https://doi.org/10.1163/092050611X590912

17. Cetinkaya S, Cinar I, Dursun HG (2017) Potential Effects of Liquidambar orientalis Mill. Against HT29 and HCT-116 Cell Lines. Proceedings 1:1061. https://doi.org/10.3390/proceedings 1101061

18. Saraç N, Şen B (2014) Antioxidant, mutagenic, antimutagenic activities, and phenolic compounds of Liquidambar orientalis Mill. var. orientalis. Ind Crops Prod 53:60-64. https://doi.org/10.1016/j.indcrop.2013.12.015

19. Sağdiç O, Özkan G, Özcan M, Özçelik S (2005) A study on inhibitory effects of siğla tree (Liquidambar orientalis Mill. var. orientalis) storax against several bacteria. Phyther Res 19:549-551. https://doi.org/10.1002/ptr.1654

20. Gurbuz I, Yesilada E, Demirci B, et al (2013) Characterization of volatiles and anti-ulcerogenic effect of Turkish sweetgum balsam (Styrax liquidus). J Ethnopharmacol 148:332-336. https://doi.org/10.1016/j.jep.2013.03.071

21. Topal U, Sasaki M, Goto M, Otles S (2008) Chemical compositions and antioxidant properties of essential oils from nine species of Turkish plants obtained by supercritical carbon dioxide extraction and steam distillation. Int J Food Sci Nutr 59:619-634. https://doi.org/10.1080/09637480701553816

22. Kim J, Seo SM, Lee SG, et al (2008) Nematicidal activity of plant essential oils and components from coriander (Coriandrum sativum), oriental sweetgum (Liquidambar orientalis), and valerian (Valeriana wallichii) essential oils against pine wood nematode (Bursaphelenchus xylophilus). J Agric Food Chem 56:7316-7320. https://doi.org/10.1021/jf800780f 
23. Lee Y-S, Kim J, Lee S-G, et al (2009) Effects of plant essential oils and components from Oriental sweetgum (Liquidambar orientalis) on growth and morphogenesis of three phytopathogenic fungi. Pestic Biochem Physiol 93:138-143. https://doi.org/10.1016/j.pestbp.2009.02.002

24. Jeon S, Bose S, Hur J, et al (2011) A modified formulation of Chinese traditional medicine improves memory impairment and reduces A $\beta$ level in the Tg-APPswe/PS1dE9 mouse model of Alzheimer's disease. J Ethnopharmacol 137:783-789. https://doi.org/10.1016/j.jep.2011.06.046

25. Erdogan E (2019) Chemical Composition and Antimicrobial Activity of Anatolian Sweetgum ( Liquidambar orientalis Mill .) Leaf Oil Chemical Composition and Antimicrobial Activity of Anatolian Sweetgum ( Liquidambar orientalis Mill .) Leaf Oil. 0-4

26. Fernandez X, Lizzani-Cuvelier L, Loiseau A-M, et al (2005) Chemical composition of the essential oils from Turkish and Honduras Styrax. Flavour Fragr J 20:70-73. https://doi.org/10.1002/ffj.1370

27. Lingbeck JM, O’Bryan CA, Martin EM, et al (2015) Sweetgum: An ancient source of beneficial compounds with modern benefits. Pharmacogn Rev 9:1-11. https://doi.org/10.4103/09737847.156307

28. Demir D, Güreş D, Tecim T, et al (2018) Magnetic nanoparticle-loaded electrospun poly( $\varepsilon$ caprolactone) nanofibers for drug delivery applications. Appl Nanosci 8:1461-1469. https://doi.org/10.1007/s13204-018-0830-9

29. Bölgen N, Menceloğlu YZ, Acatay K, et al (2005) In vitro and in vivo degradation of non-woven materials made of poly ( $\varepsilon$-caprolactone) nanofibers prepared by electrospinning under different conditions. J Biomater Sci Polym Ed 16:1537-1555. https://doi.org/10.1163/156856205774576655

30. Blois MS (1958) Antioxidant determinations by the use of a stable free radical [10]. Nature 181:1199-1200. https://doi.org/10.1038/1811199a0

31. Hsu CL, Chen W, Weng YM, Tseng CY (2003) Chemical composition, physical properties, and antioxidant activities of yam flours as affected by different drying methods. Food Chem 83:85-92. https://doi.org/10.1016/S0308-8146(03)00053-0

32. Martínez-Castañón GA, Niño-Martínez N, Martínez-Gutierrez F, et al (2008) Synthesis and antibacterial activity of silver nanoparticles with different sizes. J Nanoparticle Res 10:1343-1348. https://doi.org/10.1007/s11051-008-9428-6

33. Ceylan S, Göktürk D, Demir D, et al (2017) Comparison of additive effects on the PVA/starch cryogels: Synthesis, characterization, cytotoxicity, and genotoxicity studies. Int J Polym Mater Polym Biomater $1-10$

34. Balu R, Sampath Kumar TS, Ramalingam M, Ramakrishna S (2011) Electrospun polycaprolactone/Poly(1,4-butylene adipate-co-polycaprolactam) blends: Potential biodegradable scaffold for bone tissue regeneration. J Biomater Tissue Eng 1:30-39. https://doi.org/10.1166/jbt.2011.1004

35. Jia Y, Huang G, Dong F, et al (2016) Preparation and characterization of electrospun poly $(\varepsilon-$ caprolactone)/poly(vinyl pyrrolidone) nanofiber composites containing silver particles. Polym Compos 37:2847-2854. https://doi.org/10.1002/pc.23481 
36. Can-Herrera LA, Ávila-Ortega A, de la Rosa-García S, et al (2016) Surface modification of electrospun polycaprolactone microfibers by air plasma treatment: Effect of plasma power and treatment time. Eur Polym J 84:502-513. https://doi.org/10.1016/j.eurpolymj.2016.09.060

37. Kuppan P, Sethuraman S, Krishnan UM (2013) PCL and PCL-gelatin nanofibers as esophageal tissue scaffolds: Optimization, characterization and cell-matrix interactions. J Biomed Nanotechnol 9:1540-1555. https://doi.org/10.1166/jbn.2013.1653

38. Hermán V, Takacs H, Duclairoir F, et al (2015) Core double-shell cobalt/graphene/polystyrene magnetic nanocomposites synthesized by in situ sonochemical polymerization. RSC Adv 5:5137151381. https://doi.org/10.1039/c5ra06847a

39. Eğri Ö, Erdemir N (2019) Production of Hypericum perforatum oil-loaded membranes for wound dressing material and in vitro tests. Artif Cells, Nanomedicine Biotechnol 47:1404-1415. https://doi.org/10.1080/21691401.2019.1596933

40. Jaganathan SK, Prasath Mani M, Khudzari AZM, Fauzi bin Ismail A (2019) Physicochemical assessment of tailor made fibrous polyurethane scaffolds incorporated with turmeric oil for wound healing applications. Int J Polym Anal Charact 24:752-762.

https://doi.org/10.1080/1023666X.2019.1676010

41. Chao CY, Mani MP, Jaganathan SK (2018) Engineering electrospun multicomponent polyurethane scaffolding platform comprising grapeseed oil and honey/propolis for bone tissue regeneration. PLoS One 13:1-17. https://doi.org/10.1371/journal.pone.0205699

42. Unalan I, Slavik B, Buettner A, et al (2019) Physical and Antibacterial Properties of Peppermint Essential Oil Loaded Poly ( $\varepsilon$-caprolactone) (PCL) Electrospun Fiber Mats for Wound Healing. Front Bioeng Biotechnol 7:1-11. https://doi.org/10.3389/fbioe.2019.00346

43. Zahedi P, Rezaeian I, Jafari SH, Karami Z (2013) Preparation and release properties of electrospun poly(vinyl alcohol)/poly(É-caprolactone) hybrid nanofibers: Optimization of process parameters via D-optimal design method. Macromol Res 21:649-659. https://doi.org/10.1007/s13233-013-1064-z

44. dos Santos DM, Leite IS, Bukzem A de L, et al (2018) Nanostructured electrospun nonwovens of poly ( $\varepsilon$-caprolactone)/quaternized chitosan for potential biomedical applications. Carbohydr Polym 186:110-121. https://doi.org/10.1016/j.carbpol.2018.01.045

45. Assimopoulou AN, Zlatanos SN, Papageorgiou VP (2005) Antioxidant activity of natural resins and bioactive triterpenes in oil substrates. Food Chem 92:721-727. https://doi.org/10.1016/j.foodchem.2004.08.033

46. Chandra Mohan S, Balamurugan V, Salini ST, Rekha R Metal ion chelating activity and hydrogen peroxide scavenging activity of medicinal plant Kalanchoe pinnata. J Chem Pharm Res 2012:197202

47. Brackman G, De Meyer L, Nelis HJ, Coenye T (2013) Biofilm inhibitory and eradicating activity of wound care products against Staphylococcus aureus and Staphylococcus epidermidis biofilms in an in vitro chronic wound model. J Appl Microbiol 114:1833-1842. https://doi.org/10.1111/jam.12191 
48. Kang J, Jin W, Wang J, et al (2019) Antibacterial and anti-biofilm activities of peppermint essential oil against Staphylococcus aureus. LWT 101:639-645. https://doi.org/10.1016/j.Iwt.2018.11.093

49. Abdallah M, Khelissa O, Ibrahim A, et al (2015) Impact of growth temperature and surface type on the resistance of Pseudomonas aeruginosa and Staphylococcus aureus biofilms to disinfectants. Int J Food Microbiol 214:38-47. https://doi.org/10.1016/j.ijfoodmicro.2015.07.022

50. Salević A, Prieto C, Cabedo L, et al (2019) Physicochemical, antioxidant and antimicrobial properties of electrospun poly( $\varepsilon$-caprolactone) films containing a solid dispersion of sage (Salvia officinalis L.) extract. Nanomaterials 9:. https://doi.org/10.3390/nano9020270

51. Cetin-Karaca H, Newman MC (2015) Antimicrobial efficacy of plant phenolic compounds against Salmonella and Escherichia Coli. Food Biosci 11:8-16. https://doi.org/10.1016/j.fbio.2015.03.002

52. Lee YS, Kim J, Lee SG, et al (2009) Effects of plant essential oils and components from Oriental sweetgum (Liquidambar orientalis) on growth and morphogenesis of three phytopathogenic fungi. Pestic Biochem Physiol 93:138-143. https://doi.org/10.1016/j.pestbp.2009.02.002

53. Kido HW, Oliveira P, Parizotto NA, et al (2013) Histopathological , cytotoxicity and genotoxicity evaluation of Biosilicate ( $R$ ) glass-ceramic scaffolds Histopathological , cytotoxicity and genotoxicity evaluation of Biosilicate $V$ glass - ceramic scaffolds. https://doi.org/10.1002/jbm.a.34360

54. Mehteroğlu E, Çakmen AB, Aksoy B, et al (2020) Preparation of hybrid PU/PCL fibers from steviol glycosides via electrospinning as a potential wound dressing materials. J Appl Polym Sci 137:1-13. https://doi.org/10.1002/app.49217

55. Levorson EJ, Santoro M, Kurtis Kasper F, Mikos AG (2014) Direct and indirect co-culture of chondrocytes and mesenchymal stem cells for the generation of polymer/extracellular matrix hybrid constructs. Acta Biomater 10:1824-1835. https://doi.org/10.1016/j.actbio.2013.12.026

\section{Figures}




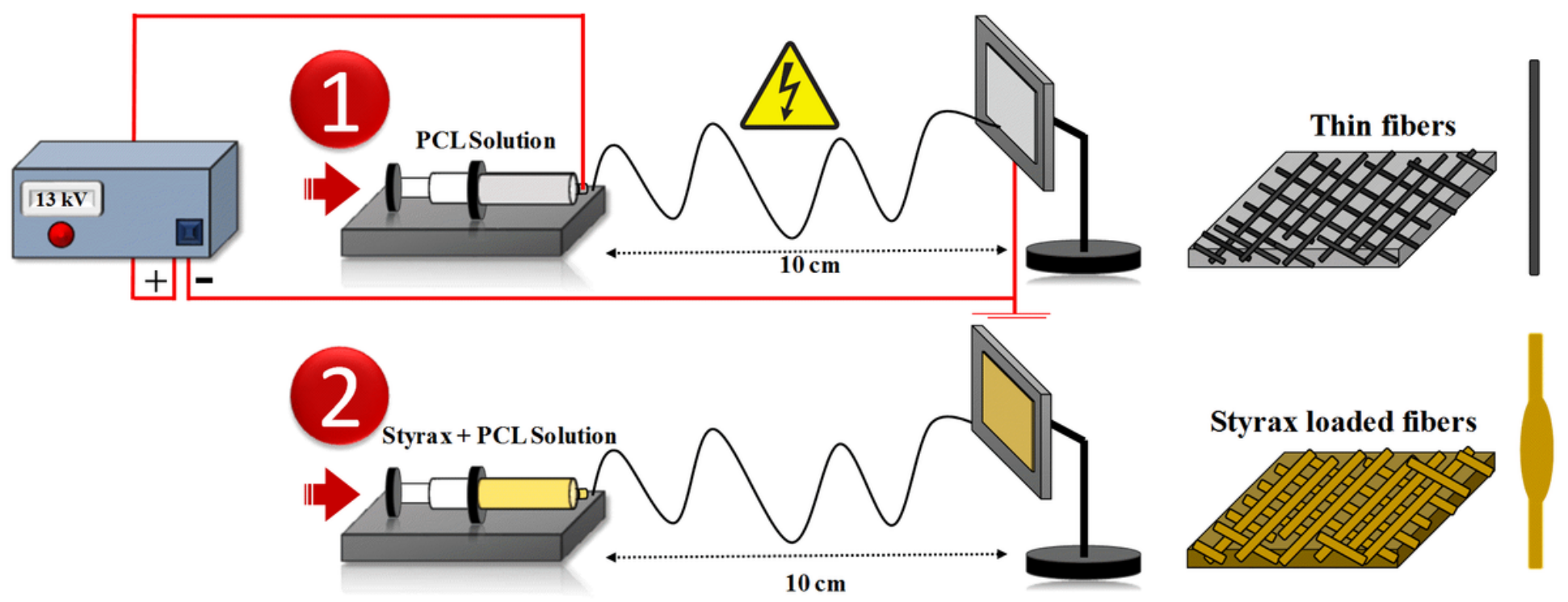

Figure 1

Schematic illustration of the experimental set-up for the fabrication of neat PCL and styrax liquidus loaded PCL composite nanofibers.
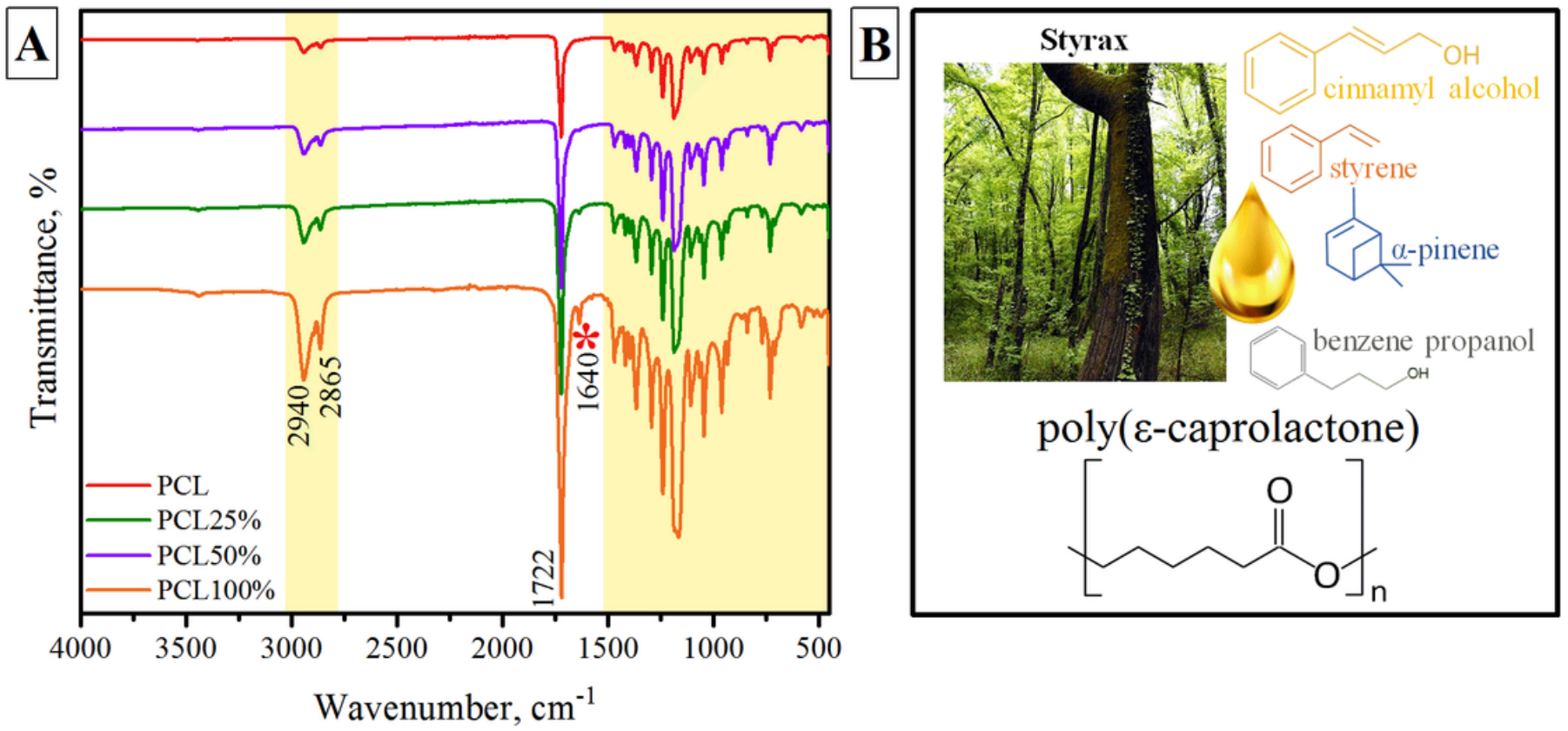

Figure 2

Chemical analysis: A) FTIR spectrum of plain PCL and styrax loaded PCL nanofibers and B) Main components of styrax and general structure of PCL polymer 

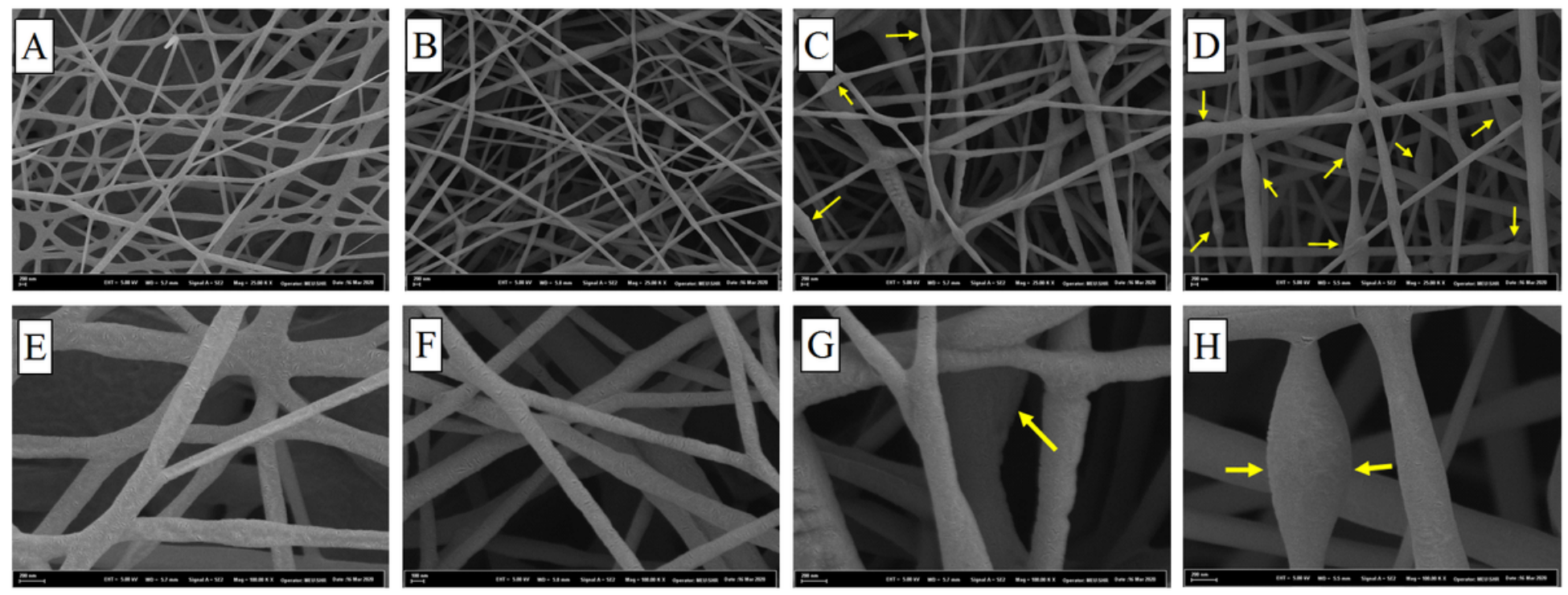

Figure 3

SEM micrographs and fiber diameter distributions of neat PCL and different amounts of styrax loaded PCL nanofibers: (A, E) PCL; (B, F) PCL25\%; (C, G) PCL50\% and (D, H) PCL100\%. 


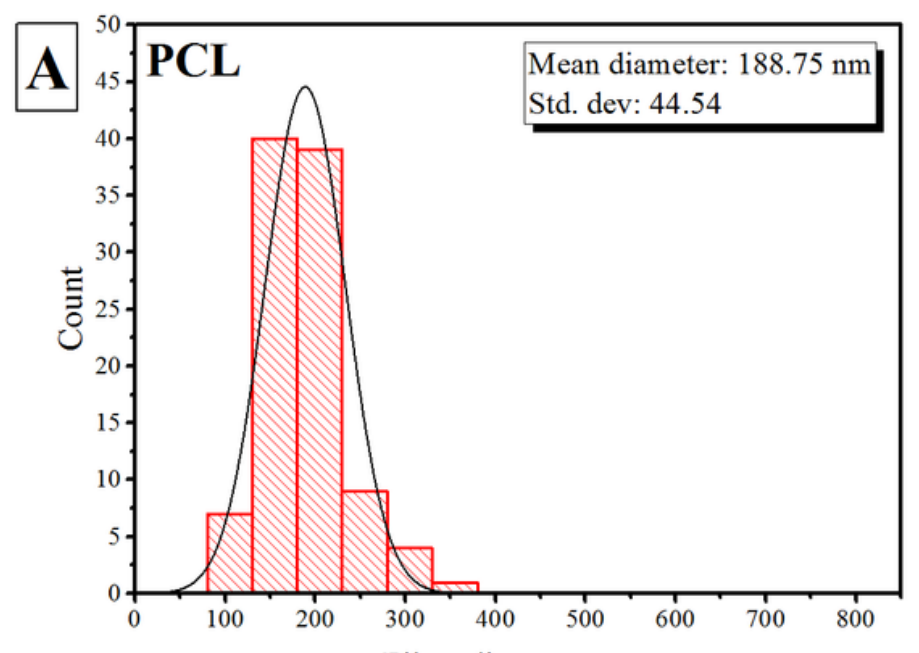

Fiber diameter, nm

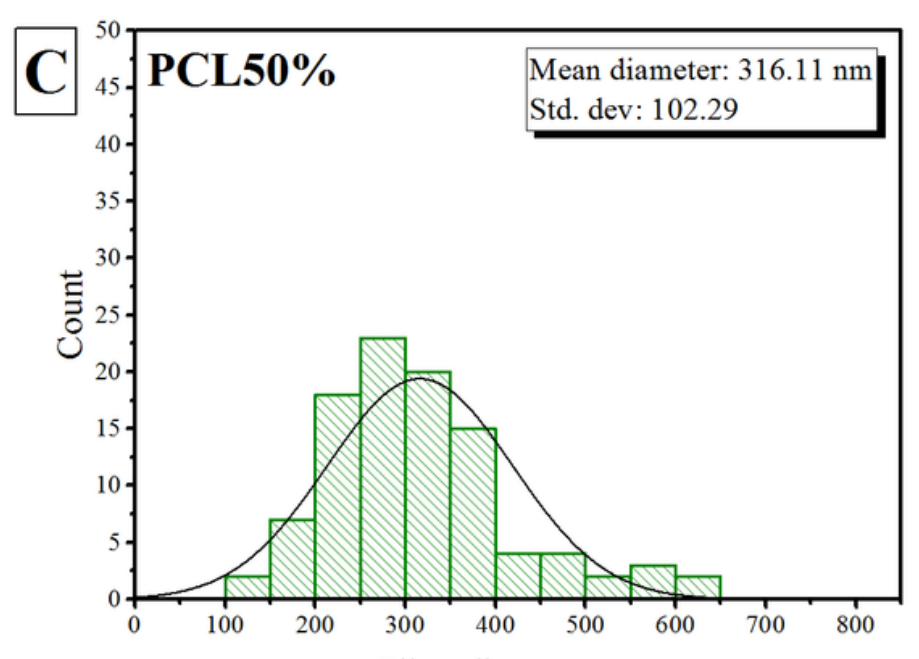

Fiber diameter, nm

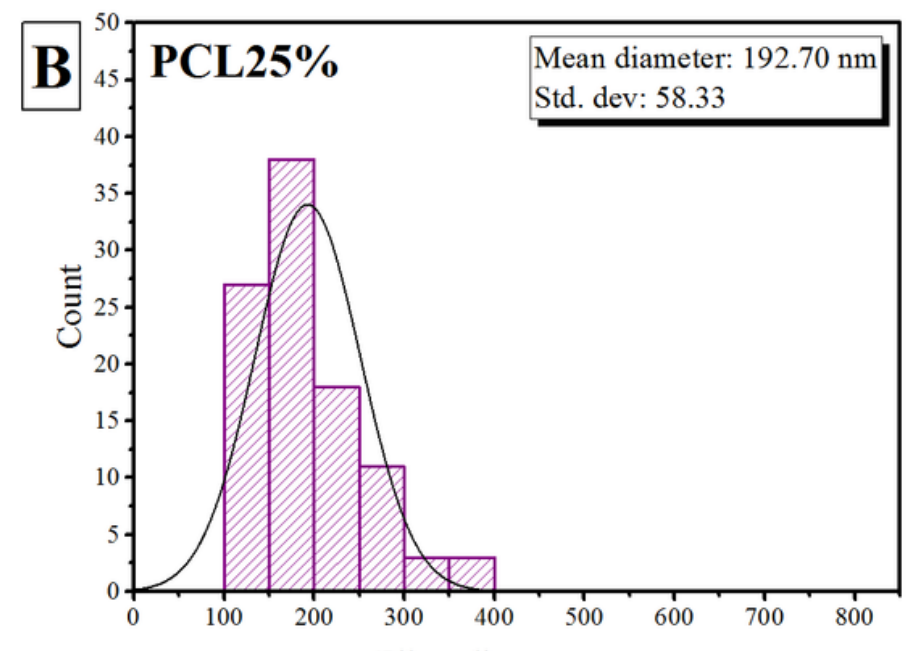

Fiber diameter, nm

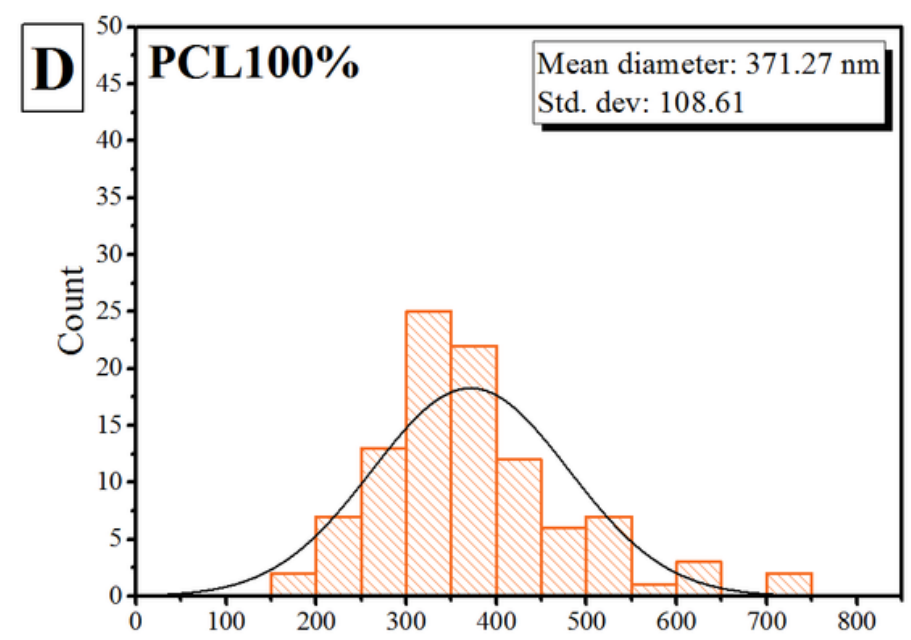

Fiber diameter, nm

\section{Figure 4}

Fiber size distribution histogram graphs of produced neat PCL and different amounts of styrax loaded composite PCL fibrous membranes. 

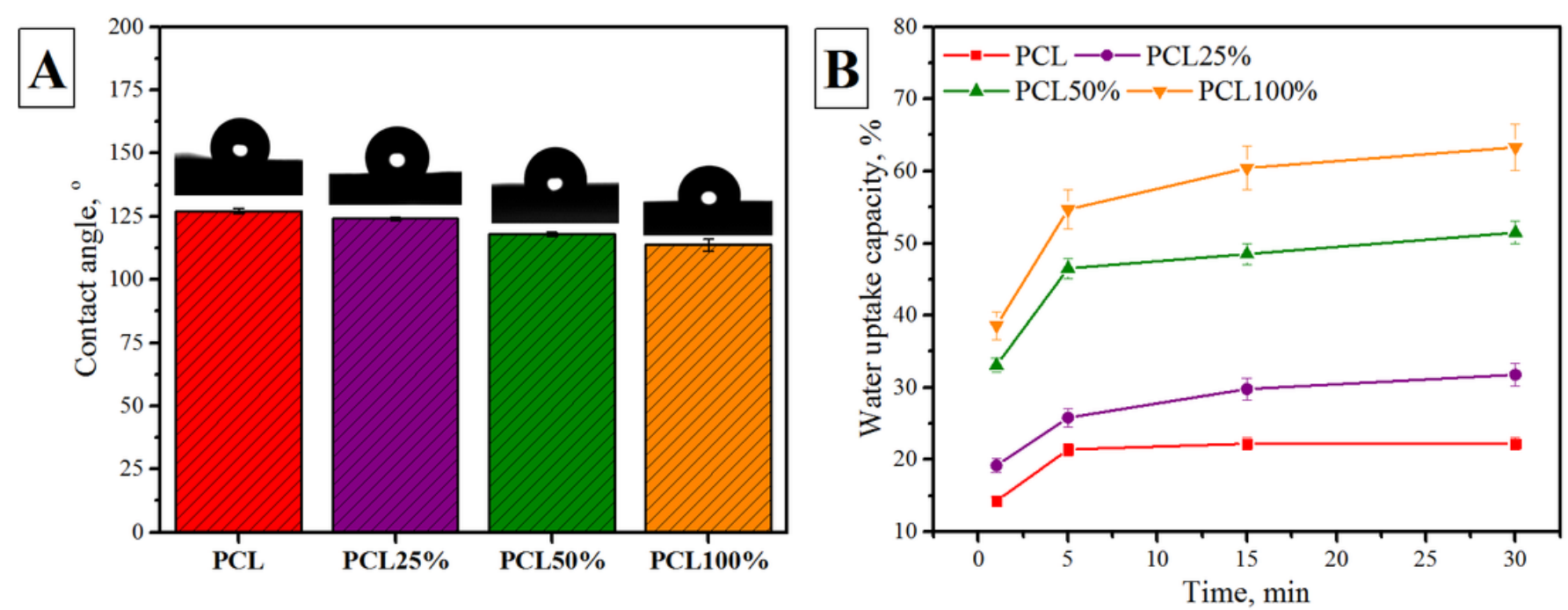

Figure 5

Measurement of hydrophilicity and wettability of neat PCL and composite nanofibers: A) Droplet profiles and contact angle evaluation of samples and B) Water uptake capacity values of samples in distilled water after 3, 5, 15 and 30 minutes. 

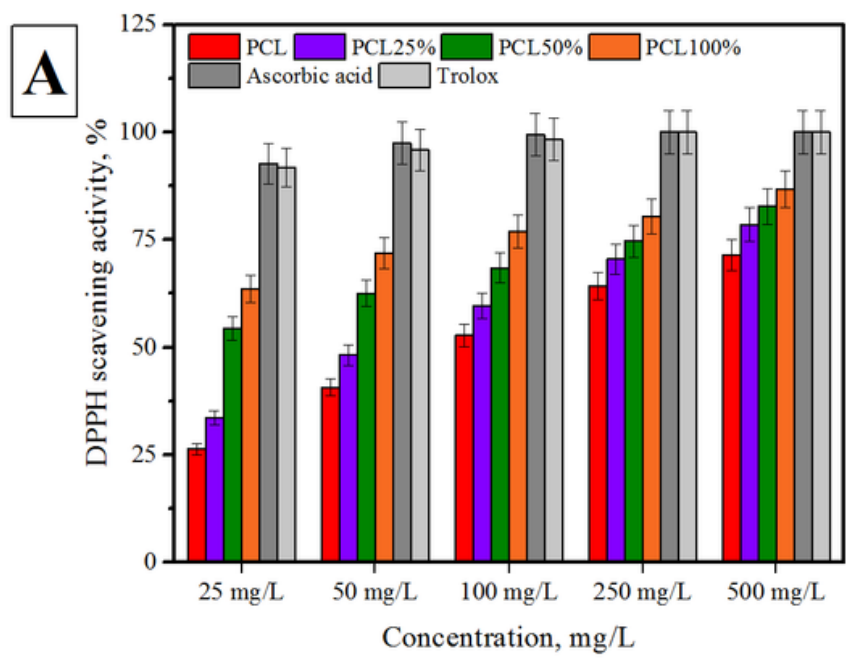

C

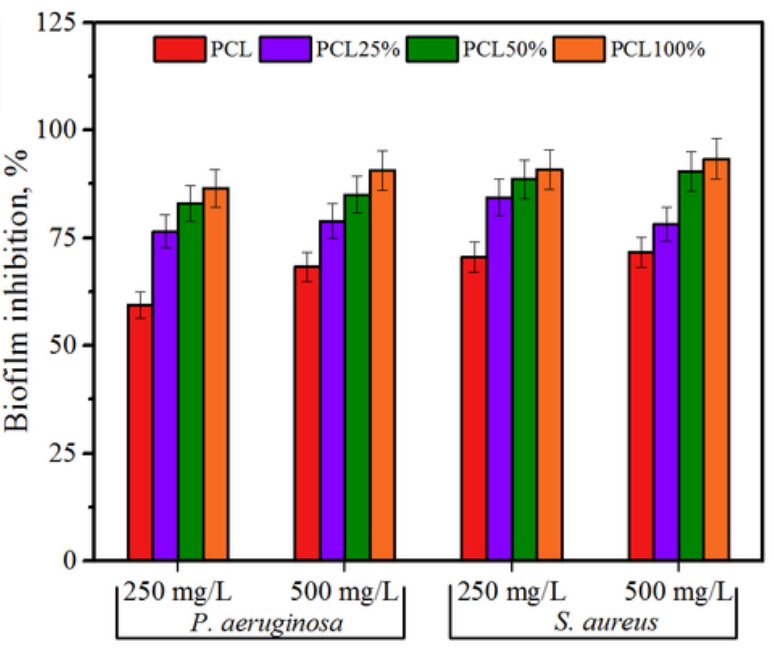

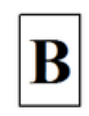

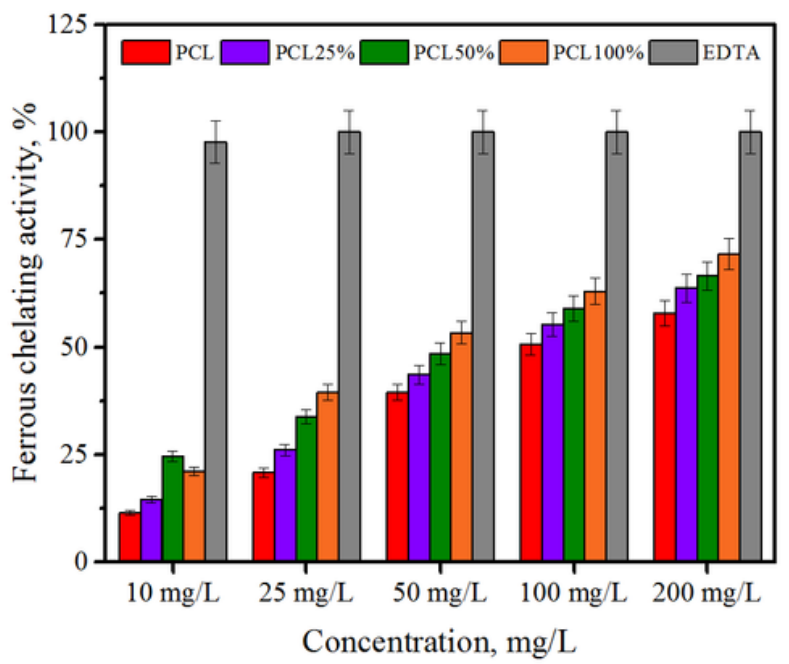

D

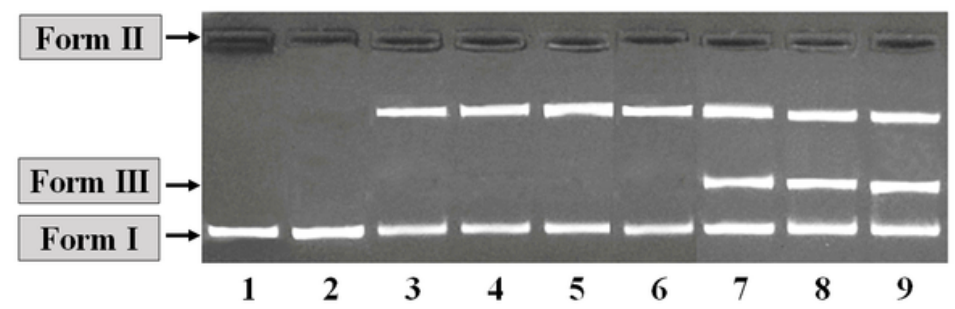

Figure 6

A) DPPH radical scavenging activities of compounds and standards, B) Ferrous ion chelating activities of compounds and standard, C) Biofilm inhibition activities of compounds and D) DNA cleavage activity of neat PCL and styrax loaded composite nanofibers. Lane 1) pBR 322 DNA, Lane 2) pBR 322 DNA+250 $\mu \mathrm{g} / \mathrm{mL}$ PCL, Lane 3) pBR 322 DNA+250 $\mu \mathrm{g} / \mathrm{mL}$ of PCL25\%, Lane 4) pBR 322 DNA+ $250 \mu \mathrm{g} / \mathrm{mL}$ of PCL50\%, Lane 5) pBR 322 DNA+250 $\mu \mathrm{g} / \mathrm{mL}$ of PCL $100 \%$, Lane 6) pBR 322 DNA+500 $\mu \mathrm{g} / \mathrm{mL} \mathrm{of} \mu \mathrm{g} / \mathrm{mL}$ PCL, Lane 7) pBR 322 DNA+500 $\mu \mathrm{g} / \mathrm{mL} \mu \mathrm{g} / \mathrm{mL}$ PCL25\%, Lane 8) pBR 322 DNA+500 $\mu \mathrm{g} / \mathrm{mL}$ of PCL50\%, Lane 9) pBR 322 DNA+500 $\mu \mathrm{g} / \mathrm{mL}$ of PCL $100 \%$. 

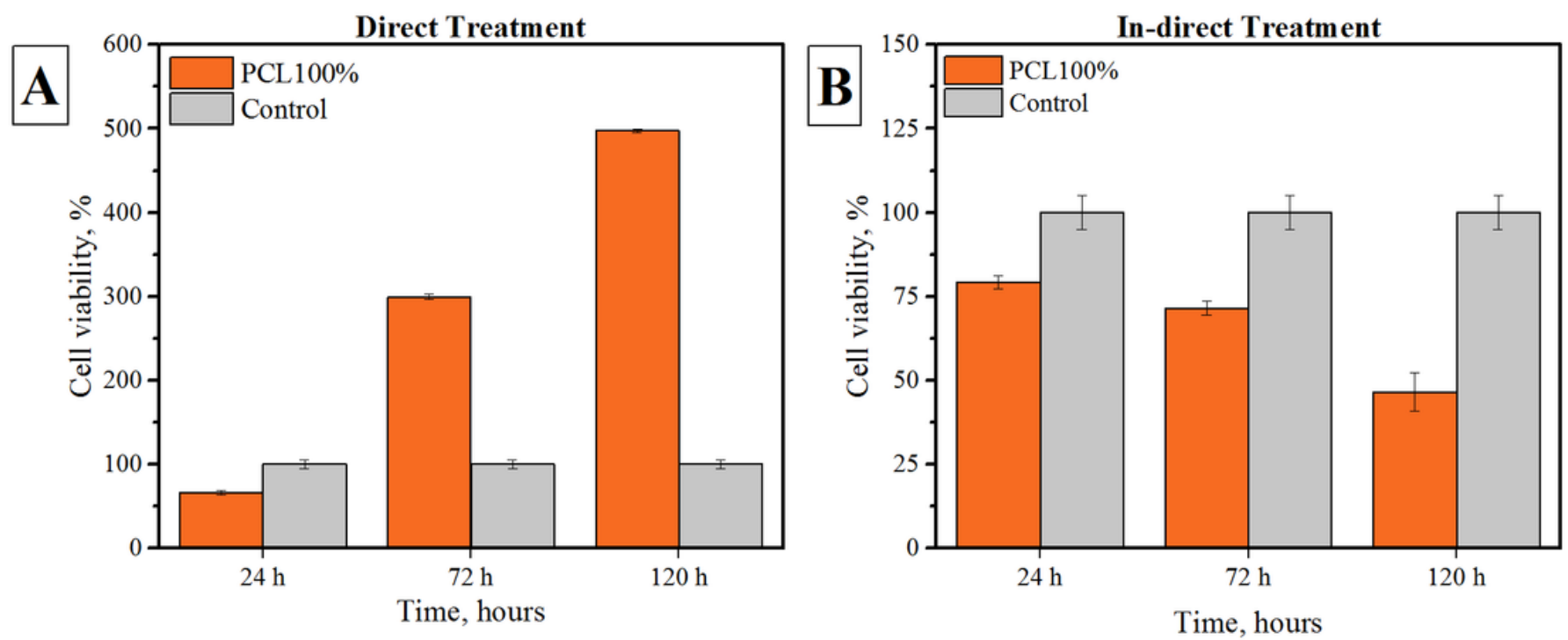

\section{Figure 7}

In vitro cytotoxicity assay results of styrax loaded PCL nanofibrous membrane in comparison with control group. A) Direct viability and B) Indirect viability results. 